Зорица Прњат

Географски факултет

Универзитет у Београду
001.811: 912.43

https://doi.org/10.18485/melissa.2017.16.1.ch18

\title{
НАВОЪЕЊЕ ГЕОГРАФСКИХ КАРАТА У СПИСКУ ЛИТЕРАТУРЕ/РЕФЕРЕНЦИ
}

\section{Сажетак}

Осим географије може се набројати цели низ наука које користе информације о простору забележене на географским картама. 3бог тога је битно знати како се карте наводе у научним чланцима у тексту рада и списку литературе/референци. Неуједначеност у том погледу која влада у научним чланцима у нашим географским часописима објашњава се чињеницом да су географи у Србији прихватили АПА стил библиографског цитирања у коме је карта занемарена као извор. Ради разрешења недоумица, у раду су предложена решења према обрасцима у страној литератури и по аналогији са навођењем књига и научних чланака.

Кључне речи: АПА стил, академско писање, географска карта, референце, библиографија

\section{1. Увод}

Географска карта дефинисана као медиј за чување географских информација (аналогна карта) или као дигитални картографски модел чији садржај одговара садржају карте одређене врсте и размера (дигитална карта) чест је извор у научним радовима, и то не само географским. У географији карте имају посебну важност јер су незаменљиве као извор информација о простору на почетку истраживања и као медиј за визуализацију добијених резултата на крају истраживања. Све географске карте, аналогне, дигиталне и електронске, представљају ауторска дела и морају се правилно навести у тексту и списку литературе/референци, као и сви други 
извори. У складу са АПА стилом који користе географи у Србији, у научним чланцима из области географије, географске карте се у тексту рада наводе једноставно: у загради се наведе презиме аутора (или назив институције/организације која је аутор карте) и година издања. Други начин је да се у тексту наведе наслов карте, дословно или описно, довољно да читалац може лако пронаћи потпуне податке о карти у списку литературе/референци на крају рада.

Када је пак у питању списак литературе, ту се појављују недоумице, јер је за карту потребно дати податке које немају књига или научни чланак: тип, размер, ознаку листа код топографских карата и сл. Прегледом спискова литературе у чланцима објављеним у српским географским часописима уочава се недоследност и неуједначеност. Ауторе делимично оправдава чињеница да у приручнику АПА стила не постоје детаљна упуства и примери за навођење географских карата. У Приручнику за објављивање (The Publication Manual of the American Psychological Association) географска карта се помиње у оквиру одељака о графичким и аудио-визуелним прилозима (2006, стр. 151 и стр. 210) и једини пример навођења географске карте у списку литературе/библиографских јединица који је дат као узор је следећи (без икаквих објашњења о наведеним подацима):

Lewis County Geographic Information Services. (Cartographer). (2002). Population density, 2000 U.S. Census [Demographic map]. Retrieved from http://www.co.lewis.wa.us/publicworks/maps/ Demographics/census-pop-dens_2000.pdf

Стога су појединци самоиницијативно или по службеној дужности (библиотекари) на вебу понудили решења до којих су дошли проучавањем других цитатних стилова и аналогијом са навођењем књига и чланака (Clark, S. M., Lynette Larsgaard, M. \& Teague, C. М., 1992; Kollen, C., Shawa, W. \& Larsgaard, M., 2010; UTA Libraries, 2016). Користећи њихове обрасце и исту методу у наставку смо понудили решења за најчешће коришћене географске карте, у разним варијантама, и то увек са општим обрасцем и конкретним примерима на српском и енглеском језику. 


\section{2. Општи обрасци и примери навођења карата у списку литературе/референци}

\section{1. Појединачна класична карта / Map on a single sheet}

Општи образац:

Аутор. (година изд.). Наслов [облик приказа]. Издање. Размер. Место издања: Издавач.

Author. (date). Title [format]. Edition. Scale. Place of publication: Publisher.

Примери:

а) Стојовић, В. и Грујић-Киш 3. (2006). Србија: манастири и иркве [карта]. 1: 600 000. Београд: Геокарта.

б) Metsker Maps. (1979). Metsker's map of Island county, Washington [map]. ca. 1:70,000. Tacoma,WA: Metsker Maps.

Напомена: Ако је аутор карте институција/организација, наводи се њено име (види пример 2.1 б); ако је година издања приближно позната онда испред бројног односа иде скраћеница „са.” (од лат. circa, приближно, отприлике), на пример (са. 1520); ако је размер приближно познат, испред бројног односа такође иде скраћеница „са.”, на пример са. 1: 70000 (види пример 2.1 б); у ситуацијама када размер није назначен, пише се: „Размер није дат”, на енглеском „Scale not given", (види пример 2.3 а-д).

\section{2 Класична атласна карта/ Map in an atlas}

Општи образац:

Аутор карте. (година изд.). Наслов [облик приказа]. Размер. У: Аутор атласа. Наслов атласа. Издање. Место издања: Издавач, страна.

Map author. (date). Map title [format]. Scale. In: Atlas author. Atlas title. Edition. Place of publication: Publisher, page. 
Примери:

а) Младеновић, А. и др. (1977). Јапан. [карта]. 1 : 7250 000. У: Младинска књига. Велики атлас света. 6.издање. Љубљана: Младинска књига, стр.80.

б) Munster, S. (1540). Ptolemaeus Tabula Europae V [map]. 1 : 4,500,000. In: S. Munster, Geographia universalis. Basel: Henrichum Petrum, p. 7.

B) Magocsi, P. R. (2003). Population movements, 1944-1948 [map]. 1 : 8890 000. In: P. R. Magocsi. Historical atlas of central Europe. (Rev. \& ex. ed.). Seattle: University of Washington Press, p. 53.

Напомена: Ако има више аутора карте, презимену последњег аутора претходи знак \&, наводе се имена првих шест аутора, након чега се ставља „и др.” на српском, односно „еt al.” на енглеском језику (види пример 2.2 a); ако је издање ревидирано и проширено, користи се скраћеница (Рев. и прош. изд.) на српском и (Rev. \& ex. ed.) на енглеском језику (види пример 2.2 в); према АПА стилу, у енглеском језику у наслову карте/атласа великим словом пише се само прва реч наслова и прва реч иза две тачке (:) и црте (-) (види пример 2.1 б, 2.2 в, 2.3 в).

\section{3 Класична карта преузета из књиге/Map from a book}

Општи образац:

Аутор карте. (година изд.). Наслов [облик приказа]. Размер. У: Аутор књиге. (година изд.). Наслов књиге. Издање. Место издања: Издавач, страна.

Map author. (date). Map title [format]. Scale. In: Book author. (date). Book title. Edition. Place of publication: Publisher, page.

Примери:

а) Радовановић, М. (2005). Климатске области Србије. [карта]. Размер није дат. У: В. Дуцић и М. Радовановић. (2005). Клима Србије. Београд: Завод за уџбенике и наставна средства, стр. 100.

б) Маријановић, М. \& Ђурић, У. (б.д.). Слика 29. Карта могућности појаве клизишта након опадања нивоа водотока после 19. 05. 2014. 
[карта]. Размер није дат. У: План управљања ризиком од природног хазарда за опитине Мали Зворник и Љубовија (2015). Београд: Унија еколога УНЕКО. Мали Зворник: ЕкоДрина. Љубовија: Омладинско удружење „Наша Љубовија”, стр. 68.

B) Đurić, V. et al. (1993). Ethnic structure of the population of the Socialist Federal Republic of Yugoslavia (SFRY). [map]. Scale not given. In: D. Hadži-Jovančić (Ed.). (1995). The Serbian question in the Balkans. Belgrade: Faculty of Geography, University of Belgrade, p. 393.

r) Yugoslavia: population [map]. (n.d.). Scale not given. In: De Blij, H. J. \& Muller, P. O. (1992). Geography: Region and Concepts. Revised sixth edition. New York: John Wiley \& Sons, Inc., p.117.

д) World ecosystem [map]. (n.d.). Scale not given. In: McKnight, T. L. (1999). Physical Geography: A Landscape Appreciation. $6^{\text {th }}$ ed. New Jersey: Pearson Prentice Hall, p.44.

\section{Напомена:}

Када карта и књига у којој се карта налази нису објављене исте године (карта је раније објављена и преузета из друге књиге, часописа или атласа), потребно је написати године издања и за карту и за књигу (види пример 2.3 в); када је непозната година објављивања карте, пише се (б.д.) (без датума) на српском или (n.d.) (no date) на енглеском (види пример 2.3 б, 2.3 г, 2.3 д); када је аутор карте непознат, библиографска одредница почиње насловом карте (види пример 2.3 г, 2.3 д).

\section{4 Класична карта преузета из научног часописа/ Map from a journal}

Општи образац:

Аутор карте. (година изд). Наслов. [облик приказа]. Размер. У: Аутор чланка. (година изд.). Наслов чланка. Назив часописа, Свеска (број свеске), страна.

Map author. (date). Map title [format]. Scale. In: Article author. (date). Article title. Journal title, Vol. (issue), page. 


\section{Примери:}

а) Тадић, М. (1990). Карта размештаја античких сунчаника на простору Југославије. [карта]. Размер није дат. У М. Тадић. (1990). Римски цилиндрични сунчаник из Дилунтума (Столац). Гласник Земаљског музеја (А). 45, 147-154.

б) Tadić, M. \& Prnjat, Z. (2016). Sundials on the territory of Serbia in 2012, and 2016 [map]. Scale not given. In: Tadić, M. \& Prnjat, Z. (2016). Sundials as environmental posters. The Environment, 4, 1, 13-17.

Напомена:

Када карта и чланак у којој се карта налази нису објављени исте године (карта је раније објављена и преузета из другог извора), потребно је написати године издања и за карту и за чланак; када је непозната година објављивања карте, пише се (б.д.) (без датума) на српском или (n.d.) (no date) на енглеском; када је аутор карте непознат, библиографска одредница почиње насловом карте.

\section{5 Класична топографска карта/Map in a topographic series}

Општи образац:

Наслов карте [облик приказа]. (година издања). Издање. Размер, број листа. Место издања: Издавач.

Map title. [format]. (date). Edition. Scale, sheet number. Place of publication: Publisher.

\section{Примери:}

а) Ваљево 4 [топографска карта]. (1984). Друго издање. 1 : 50 000, 478-4. Београд: Војногеографски институт.

б) Brantford, Ontario. [map]. (1994). Edition 7. 1:50,000. Canada 1:50,000, 40P/1. Ottawa: Canada Centre for Mapping.

1.6 Онлајн карта (статична дигитална карта на вебу) /Map (static) on the web

Општи образац када је аутор познат:

Аутор карте. (година издања). Наслов карте [облик приказа]. Размер. „Назив веб сајта” 
$<U R L>$ (датум приступања).

Map author. (date). Map title [format]. Scale. "Title of website" $<U R L>$ (date accessed).

Општи образац када аутор није познат:

Назив институције у оквиру које је карта настала [картограф]. (Година израде карте).

Наслов карте. [облик приказа]. Размер. „Назив веб сајта” <URL> (датум приступања).

Примери:

а) Радовановић, С. и др. (2012). Карта епицентара земљотреса за период 1456-2012. година Mw>=3.0 [карта]. Размер није дат. „Републички сеизмолошки завод, Република Србија” <http://www. seismo.gov.rs/Seizmicnost/Karta_epicentara_c.pdf> (приступљено 01. 04. 2018.).

б) Serbia [map]. (n.d.).Visual Scale. "The World Factbook: Serbia" $<$ https://www.cia.gov/library/publications/the-world-factbook/geos/ ri.html> (Accessed

April 1, 2018).

в) Републичка агенција за просторно планирање [картограф]. (2010). Коришћење земљишта и функционална урбана подручја [карта]. Размер није дат. „Републичка агенција за просторно планирање" <http://www.rapp.gov.rs/prostorni-plan-republike-srbije/cid310-83174/prostorni-plan-republike-srbije> (приступљено 01.04.2018.).

\section{Напомена:}

Када аутор није познат, што није редак случај, онда на прво место долази назив институције/организације у оквиру које је карта настала (која је носилац ауторских права), што се назначава у угластој загради (види пример 2.6 в); када није назначена ни институција, библиографска одредница почиње насловом карте (види пример 2.3 г, 2.3 д, 2.6 б); када није позната година објављивања карте, пише се (б.д.) (без датума) на српском или (n.d.) (no date) на енглеском (види пример 2.3 6, 2.3 г, 2.3 д, 2.6 б). 


\section{7 Онлајн карта (интерактивна дигитална карта на вебу) /Interactive Map created from Website}

Општи образац:

Наслов карте. Употребљени лејери. Размер. Име особе која је сачинила карту;

коришћењем „Назив веб сајта” <URL> (датум приступања).

Map title. Layers used. Scale. Name of person who generated map; using "Title of Website"

$<U R L>$ (date accessed).

\section{Примери:}

а) КО Мионица. Употребљени лејери: катастарске парцеле. $1: 1$ 250. Карту урадила Зорица Прњат употребом „Дигитална платформа за Националну инфраструктуру геопросторних података" “ < https:// a3.geosrbija.rs/> (01. 04. 2018.).

б) Statistics Canada. Less than grade 9, population 20 years and over by highest level of

schooling as \% of Total Population. Hamilton [172 areas]. Layer used: 2001 Census of

Population. Scale unknown. Map generated by Cathy Moulder; using "E-Stat"

<http://estat.statcan.ca/> (Accessed July 20, 2004)

\section{Напомена:}

Код онлајн карата размер се уписује само када то има смисла, јер код највећег броја ових карата размер је промењив (карта се може увећати или умањити).

\section{Закључак}

У научно-истраживачком раду географска карта се користи за прикупљање геопросторних података о простору и за визуализацију 
резултата. Свака коришћена карта мора се навести у научном чланку у тексту и у списку литературе. За разлику од текста рада где се карта наводи као и свака друга публикација (аутор/институција, година издања) навођење у списку литературе није тако једноставно. Први разлог је разноврсност географских карата, посебно оних из групе тематских: у склопу система географских наука постоји на десетине научних дисциплина, физичкогеографских и друштвеногеографских, од којих свака има своје тематске карте. Други разлог је тај што је у АПА стилу који користе географи у Србији дат уопштен образац за навођење географских карата без објашњења како се он примењује код различитих географских карата (као што је то детаљно разрађено за остале публикације).

Предуслов за првилно навођење географске карте у списку литературе јесте добро познавање правила навођења књига и часописа у АПА стилу. По аналогији у односу на та правила и на основу сугестија и примера које дају појединци на вебу, потребно је у постојеће обрасце унети и податке специфичне за географске карте. Осим имена аутора (или назива институције која је аутор карте), наслова карте, наслова атласа код атласних карата или наслова публикације у којој се карта налази, назива издавача, места и године издања, потребно је дословно назначити да се ради о географској карти (карта), а затим додати врсту карте, њен размер, формат, технику штампе код старих карата и ознаке код карата урађених у више листова (међународна карта света, топографске карте и сл.). Руководећи се свим наведеним захтевима настали су обрасци и примери у овом раду, али не у смислу готових решења већ као основа на којој би се у будућој верзији АПА стила могла разрадити и прописати обавезујућа правила за навођење географских карата.

\section{Извори и литература}

American Psychological Association. Publication Manual of the American Psychological Association (6th ed.). Washington DC: American Psychological Association, 2010.

Clark, Suzanne M., Mary Lynette Larsgaard and Cynthia M. Teague. Cartographic Citations: $A$ 
Style Guide. Chicago: American Library Association, Map and Geography Round Table, MAGERT Circular No. 1, 1992.

Kollen, Christine, Wangyal Shawa and Mary Larsgaard. Cartographic Citations: A Style Guide. 2nd ed. Chicago, IL: Map and Geography Round Table, American Library Association, 2010. University of Texas (Arlington). UTA Libraries Map Guide: Citing Maps. Arlington: University of Texas at Arlington, 2016. Online. http://libguides.uta.edu/maps (Accessed April 1, 2018).

\section{Zorica Prnjat}

\section{CITING MAPS IN REFERENCE LISTS}

\section{Summary}

In addition to geography, there are other sciences that use spatial information provided on maps (analog or digital), which means that maps must be correctly cited in research papers, in text and in literature/reference list. In Serbia, geographers use APA citation style, which has been made for other scientific disciplines and in which a map is completely neglected as a source. In order to solve the dilemma encountered by authors of research papers (which is evident from the inconsistencies of citations in national scientific journals), on the basis of solutions offered and patterns found in foreign sources on the web, in this paper the solutions for citing various forms of maps in reference lists have been proposed and illustrated with concrete examples in Serbian and English. 